\title{
Constitutional Spheres and Forms of Interaction among Chamber in Modern Parliaments
}

\author{
Ludmila I. Nikonova ${ }^{1}$, Marina V. Markhgeym ${ }^{1}$, Alevtina E. Novikova ${ }^{1}$, Anna A. Minasyan ${ }^{1} \&$ Natalya N. \\ Kurova $^{2}$ \\ ${ }^{1}$ Belgorod State University, 85 Pobedy Street, Belgorod, the Belgorod region, Russia \\ ${ }^{2}$ Pitirim Sorokin Syktyvkar State University, 55, Oktyabrsky prospect, Syktyvkar, Komi Republic, Russia \\ Correspondence: Ludmila I. Nikonova, Belgorod State University, 85 Pobedy Street, Belgorod, the Belgorod \\ region, 308015, Russia. E-mail: russia@prescopus.com
}

Received: June 19, 2017

doi:10.5539/jpl.v10n4p201
Accepted: July 18, 2017 Online Published: August 30, 2017

URL: https://doi.org/10.5539/jpl.v10n4p201

\begin{abstract}
Abstarct
The article is devoted to the identification of spheres and associated forms of interaction between the chambers of modern bicameral parliaments. It was noted that the constitutional forms of inter-chamber cooperation differ by considerable variety and depend on a legal status of chambers. On the basis of constitutional legislation analysis, the article proposes the systematization of spheres and the forms of interaction between the chambers of parliaments.
\end{abstract}

Keywords: constitution, parliament, bicameralism, chambers of parliament, joint sessions of chambers, spheres of interaction between chambers, chamber interaction forms

\section{Introduction}

Modern parliaments are studied from the point of essence and functioning (Rogers \& Walters, 2015; Palmer, 2015; Beetham, 2006) in the country (Kriesi, 2001; Remington, 2008; Norton, 2013; Bach, 2003; Ziegenhain, 2008) and European (Dann, 2003; Judge \& Earnshaw, 2008) aspects; political (Easton, 1953) and party (Kreppel , 2002; Hix et al., 2003) conjugation, etc. The problems of interaction between chambers are concerned only with those countries that have bicameralism (Tsebelis, 1997) and are designed contextually. We propose to pay attention to the interaction of bicameral parliament chambers in order to identify the possible spheres and forms of their cooperation. The relevance of this trend is conditioned by the constitutional design of a parliament as a single body that implements a general state (legislative, control, personnel, etc.) policy.

\section{Methodology}

The study was based on a dialectical approach to the study of processes and phenomena using general scientific (system and logical analysis and synthesis) and private-science methods. The latter included formal-legal, historical-legal, comparative-legal approach, assuming the exchange of information at the level of the world legal science and the search of new parameters to compare the phenomena of legal reality in different countries.

\section{Discussion and Results}

A vivid example of an organic unity of chambers within the legislative body of power can be represented by the Art. 24 of the French Constitution of 1958, which states: "Parliament adopts laws. It controls the activities of the Government. Parliament assesses state policy. Parliament consists of the National Assembly and Senate. "Sec. 1 of the article I in the US Constitution of 1787 stipulates that "legislative power belongs to the Congress of the United States, which consists of the Senate and the House of Representatives". According to the Art. 44 of the Constitution of the Federal Republic of Brazil, 1988 "Legislative power is exercised by the National Congress, which consists of the Chamber of Deputies and the Federal Senate". Similar wordings are contained in the constitutions of Thailand, 2007 (Article 88), of the Czech Republic, 1992 (Article 15), of Japan, 1947 (Article 42), etc.

The conditionality of mutual relations between the chambers was precisely and shortly formulated by the well-known Russian Constitutionalist V.E. Chirkin: "the bicameral nature of chambers makes them to interact" (Chirkin, 2011, p. 137). Accordingly, the constitutions and the regulations of the Chambers in the countries with 
a similar structure of a legislative body provide for various organizational, functional, procedural and other measures to ensure the cooperation of chambers.

One of the constitutional interaction forms between chambers is represented by joint meetings. Thus, Art. 136 of the Kingdom of Thailand Constitution, 2007 contains a detailed list of 16 reasons to hold joint meetings of the House of Representatives and the Senate, among which the confirmation or approval of the throne succession, the adoption of the National Assembly procedure rules, the declaration of war approval, a draft or a project of an organic law consideration, etc.

Some constitutions leave open a list of issues to gold joint meetings. For example, according to Art. 37 of the Czech Republic Constitutions, 1992 the joint sessions of the Chambers are convened by the Chairman of the Chamber of Deputies, but there is no list of reasons to hold such meetings. The determination of issues for a joint meeting of the Chamber of Deputies and the Senate are purely "discretionary powers of the lower chamber President".

The reasons of joint meetings can be different: ceremonial (taking the oath of office by a head of state - Article 91 of the Constitution of Italy, 1947), listening to the information provided by the President about the state of affairs in the country (Section 3, Article II of the United States Constitution, 1787), listening to a monarch's throne speech, containing the government program for the coming year (Great Britain), overcoming the President's veto (paragraph 4, article 66 of the Brazilian Constitution of 1988) or the King's veto (Article 151 of Thailand Constitution, 2007), the decision to declare war (par. 11, section 8, article I of The United States of America Constitution, 1787, article 78 of the Italian Constitution of 1947), etc.

A joint meeting can also be used as a means of inter-chamber conflict resolution. So, in Australia, in case of a legislative conflict between the House of Representatives and the Senate, a Governor-General has the right to dissolve both chambers simultaneously. If, after such dissolution the Federal Parliament chamber fails to reach an agreement concerning an issue again, a joint meeting is formed at which this issue is solved by a majority vote from the total number of the Senate and the House of Representatives members.

Proceeding from the functional certainty, bicameralism determines the interaction of chambers in the legislative process. The world practice represents a significant variety of interaction forms between chambers in the legislative sphere. They include, for example, the approval of the draft law in both houses within an identical edition (Part 2, Article 107 of the Republic of India Constitution, 1949, Article 59 of Japan Constitution, 1947); "Silent consent" (Part 2, Article 121 of the Constitution of Poland, 1997 "... if the Senate does not adopt a relevant order within 30 days from the date of a law transfer, the law shall be considered adopted in the edition adopted by Seim"), the resolution of disagreements on a draft law.

We think it necessary to comment on the latter. In some countries, in order to overcome a negative position from one of the chambers, it is possible to vote again on a draft law in a chamber with greater powers. So, if the House of Councilors of Japan does not approve a draft law of the House of Representatives within 60 days after its receipt, the draft law is considered as rejected. To overcome the Chamber of Advisers veto, a second vote is necessary with the approval of at least two-thirds of the deputy votes in the lower house (Article 59 of the Constitution of Japan, 1947). An absolute majority may take place. For example, to overcome the objections of the House of Lords in the UK, a repeat vote in the House of Commons may be sufficient, but at least after one year after the first voting in the lower house (Act on the Parliament, 1949). Such a procedure is provided by Part 1. Art. 47 of the Czech Republic Constitution in 1992, according to which a second voting is held in case of rejection of the draft law by the Senate in the Chamber of Deputies. The draft law will be considered as adopted if more than half of the total number of deputies voted for it.

The possibilities of the upper house influence on the content of an adopted law are very limited in this case and in fact its role is reduced to the approval or disapproval of a ready-made legislative decision. In a number of countries this is possible within the framework of the same session of the parliament, but in the UK, for example, it is possible only at another session. Since a session is convened once a year in this country, it means theoretically that the House of Lords can delay the adoption of the law for a year.

With regard to financial bills in such countries, the upper house does not have the right to apply a veto. It can only delay the entry of financial laws into force, for example, for 30 days in Japan (Article 60 of the Japan Constitution, 1947).

The analysis of constitutional acts made it possible to identify conciliation procedures as a form of interaction and as a way of achieving a compromise between the chambers with equal rights. In this case, the development of conciliation commissions is provisioned. Thus, in France Presidents have the right to "convene a meeting of a 
mixed parity commission authorized to propose an act concerning problematic provisions" as the result of disagreements between the chambers (Part 2, Article 45 of the French Constitution, 1958).

The overcoming of discrepancies between chambers in the legislative process is also achieved through so-called quasi-consensus approaches. For example, in Spain, according to Art. 74 of the Constitution of 1978, when, according to the text submitted by the combined commission (consisting of the same number of deputies and senators) no agreement is reached between the Congress of Deputies and the Senate, the issue is decided by the Congress using an absolute majority of votes.

Besides, joint meetings are the form of an agreed opinion achievement between chambers according to a draft law under issue where decisions are taken by the majority of votes of both chamber members (Part 4, Article 108 of the Indian Constitution, 1949). In V.E. Chirkin's opinion, the separation of chambers provides a versatile and a balanced approach to a draft law, enables the chamber, representing the interests of the territories, to express their will. Besides, the House of Representatives is often more numerous, which allows it to overcome theoretically always the opinion of another chamber (Chirkin, 2011, p. 74).

Along with the situational forms of interaction between the chambers of the parliament, there are also permanent ones provided constitutionally. In particular, chambers create common bodies in the form of commissions and committees on a parity basis to prepare for the discussion of laws during a plenary session, as well as to resolve other issues. They can work on a permanent and temporary basis. The examples of the first approach are the Joint Committee on Human Rights in the UK Parliament or the Joint Committee of the Bundestag and the Bundesrat deputies (Article 53 of the FRG Basic Law, 1949). The second approach can be illustrated using the example of a chamber representative conference in the US Congress, convened to consider relevant proposals to improve any branch of legislation or the work on a specific draft law. The decisions taken by such bodies can be of different force: in some cases, the decision of the commission is recommendatory and must be approved (or rejected) by the chambers; In other cases, the commission can take a final decision on a law, after which an act is sent to a head of state for signature and promulgation.

In addition to the legislative cooperation of the Parliamentary Chambers in the above-mentioned forms, they cooperate on other issues.

The sphere of the conjugation of the chamber powers typical for most modern states is the organizational and personal one, which prescribes the joint development of state power higher bodies or the appointment of officials. The analysis of foreign country constitutions made it possible to identify here four forms of interaction between the parliament chambers.

The first assumes the parity participation of chambers. In Germany, for example, the members of the Federal Constitutional Court are elected equally (by 8) by the Bundestag and the Bundesrat (Article 94 of the Basic Law of the Federal Republic of Germany, 1949), in Italy a joint session of the Parliament Chambers appoints five judges of the Constitutional Court of Italy (p. 1, art. 135 of the Italian Republic Constitution, 1947).

The second one is a parity-attracted, when the chambers of the parliament draw the representatives of the federation subjects or administrative-territorial units to the elections of the state head (Article 83 of the Constitution of Italy, 1947, article 52 of the Indian Constitution, 1949).

The third form is parity and conciliation, as, for example, in Poland: the Chairman of the Supreme Control Chamber (Part 1 of the Article 205 of the Constitution of Poland, 1997) and the Advocate for Civil Rights (Part 1, Article 209) are appointed by Seim, but with the Senate consent. In Japan, if an agreement is not reached on the candidacy of the Prime Minister through a joint session of the Chamber of Advisers and the House of Representatives, the decision of the lower house becomes the decision of the entire Parliament (Article 67 of the Constitution of Japan, 1947).

The fourth form is parity-vacation, when representative commissions (parliamentary deputations) developed by both chambers are constitutionally provided for work during parliamentary holidays. Their numbers are accurately recorded sometime in the constitutions (according to Article 78 of the Constitution of Mexico, 1917 "The Constant Committee consists of 29 members, of which 15 are the Deputies, and 14 are the Senators appointed by the respective Chambers during the last session before an ad journal") or maybe not defined (par. 4, article 58 of the Brazilian Constitution of 1988 "the composition of the commission should be proportional to the representation of political parties as much as possible").

The sphere of cooperation among the chambers of foreign parliaments is recognized as the controlling one. There are the grounds to distinguish three varieties within its framework - personnel control, organizational control and financial control. 
The first one is realized in connection with the removal from office (impeachment) or the resignation of the highest state officials. There is a significant difference in the regulation of initiators and the procedural rules for constitutional responsibility application. The most complete powers in this sphere belong to the US Congress, since the House of Representatives initiates charges against federal officials (President, Vice President, ministers, governors, federal judges, ambassadors), and the Senate (if the President's case is handled the Chief Justice of the Supreme Court is at the head of the Senate) makes a decision on their guilt or innocence by a qualified majority $(2 / 3)$ of the votes.

In France, "the dismissal of the President is exercised by the Parliament, constituting the Supreme Court". The initiative should proceed from $10 \%$ of the senators and $10 \%$ of the deputies of the National Assembly at least, and two thirds of each of the chamber members must support it. The President of the National Assembly presides over the Supreme Court, established on equal origins by the National Assembly and the Senate. If the Supreme Court decides to impeach a President, then he acts as the Supreme Court of general competence. In Italy, the President of the Republic is tried by the Parliament at a joint session of the Chambers by an absolute majority of its members (Article 90 of the Constitution, 1947), and the decision on the charge put forward under the Constitution is referred to the Constitutional Court powers (art. 134).

The variation of the personnel-control interaction between the parliament chambers is an expression of distrust to the ministers. In the constitutional format this option is fixed in some Latin American states. Thus, in Colombia and Paraguay deputies can express distrust to ministers "in connection with their official duties" during the joint sessions of chambers (Chirkin, 2011, p. 108).

The joint activity of the chambers is also expressed in the control over delegated legislation (with the provision of relevant powers to the government). The delegation of legislative powers by both chambers of parliament is provided by Art. 76 of the Italian Constitution of 1947, according to which "the exercise of the legislative function can be delegated to the Government, provided that the principles and the guiding criteria of such a delegation are determined and it is provided only for a limited time and on a certain range of issues".

The second organizational and control variety is realized in connection with the right of chambers to create joint permanent and temporary commissions. Permanent commissions mediate reports of ministers on the activities of the ministries headed by them. In the United States and in the presidential republics of Latin America, the information from the heads of federal agencies is discussed at joint meetings of chambers regularly, although binding decisions on such reports are not taken by executive bodies, but these materials are taken into account in its Legislative activity (Chirkin, 2011, p. 119).

In Italy, permanent bicameral commissions with control powers are set constitutionally. Their establishment helps to eliminate unnecessary duplication of functions in the Italian parliament chambers, which have equal status. So, the control over the activities of the regional councils is carried out by the constant Committee on local issues, which consists of 20 deputies and 20 senators, taking into account the representation of all regions of the country and the members of the various parliamentary groups.

Temporary joint commissions may have an "investigative" character. According to Art. 76 of the Spanish Constitution of 1978, an investigation commission can be developed in connection with the consideration of any matter of public interest, and its conclusions can be transferred to the prosecutor's office. In accordance with $\S 3$, Section VII, Ch. I of the Constitution of Brazil (1988) the same commissions have the authority to conduct their own investigations as judicial bodies. They are developed by the Chamber of Deputies and the Federal Senate at the request of one third part of these chambers' members, and the conclusions of the commissions can be sent to the prosecutor's office to bring perpetrators to the civil or criminal responsibility.

The third financial and control variety of joint activities of the parliament chambers concerns the state budget, the establishment of taxes and levies, tax benefits, the decision-making on external and internal loans of the state, monetary emission and on the creation of diverse extrabudgetary funds, etc. Moreover, it can be referred to the legislative sphere, since it is implemented in the form of law adoption. Thus, in accordance with the Constitution of Italy (Article 81), both chambers approve the budget submitted by the Government and the law in its execution annually.

Let's also designate the cooperation of the parliament chambers in the international sphere. Constitutional practice provides the evidence that the parliament traditionally is entitled to ratify and denounce international treaties. The constitutions of a number of countries stipulate that both chambers of the parliament are given with the consent to the conclusion of a treaty traditionally. For example, in the Spanish Constitution of 1978 (Article 94), the prior consent of the General Cortes is required for those treaties and agreements that contain political, military and financial obligations, affect the territorial integrity of the state or imply the adoption, modification 
or abrogation of laws.

The subsequent approval of a concluded agreement is also possible. Part 1, Art. 49 of the Constitution of Brazil (1988), refers to the National Congress competence the adoption of final decisions on international treaties, the agreements or acts that entail obligations or encumbrances on national property that makes the property of the state. The same order is traditionally provided for the denunciation of treaties as for their ratification.

\section{Conclusions}

Taking into account the mentioned above, it should be noted that the interaction spheres and forms between the chambers of parliaments presented in the constitutional legislation of foreign countries allow one to judge the approaches of states to their status development.

Typical constitutional spheres of interaction between the chambers of bicameral parliaments are legislative, organizational, personnel and control one; typical constitutional forms are the joint meetings on a specific or a variety of issues and occasions, as well as the resolution of inter-chamber conflicts.

The most varied forms of interaction between the chambers of parliaments are stipulated in the legislative process, which is related to the functional certainty of the parliament. Among such forms is the approval of the draft law in two houses in an identifiable form, a tacit agreement, the use of the veto, conciliation procedures, the creation of joint situational or permanent bodies.

We have determined four forms of interaction between the chambers of parliaments in the organizational and personnel sphere: parity-staff, parity-attracted, parity-conciliation and parity-vacation.

We determined three forms of interaction between the Chambers of Parliaments in the control sphere: personnel control, organizational control and financial control.

The proposed author's approach to the systematization of interaction spheres and forms between the Chambers of Parliament in the article is aimed on the search for their cooperation effective system and for further development of scientifically based recommendations on the optimal use of modern parliamentarianism resources, etc.

\section{References}

Bach, S. (2003). Platypus and parliament: The Australian senate in theory and practice (p. 7). Department of the Senate Parliament House.

Beetham, D. (Ed.). (2006). Parliament and democracy in the twenty-first century: A guide to good practice. Inter-Parliamentary Union.

Chirkin V. E. (2011). The upper house of the modern parliament: a comparative legal study. M: Norma: INFRA-M, 144 pp. (in Russian)

Dann, P. (2003). European Parliament and Executive Federalism: Approaching a Parliament in a Semi-Parliamentary Democracy. European Law Journal, 9(5), 549-574. https://doi.org/10.1046/j.1468-0386.2003.00192.x

Easton, D. (1953). The political system (pp. 266-306). New York: Knopf.

Hix, S., Kreppel, A., \& Noury, A. (2003). The party system in the European Parliament: Collusive or competitive? JCMS: Journal of Common Market Studies, 41(2), 309-331. https://doi.org/10.1111/1468-5965.00424

Judge, D., \& Earnshaw, D. (2008). The European Parliament. Palgrave Mac-millan. https://doi.org/10.1007/978-1-137-07775-2

Kreppel, A. (2002). The European Parliament and Supranational Party System: a study in institutional development. Cambridge University Press.

Kriesi, H. (2001). The federal parliament: the limits of institutional reform. West European Politics, 24(2), 59-76. https://doi.org/10.1080/01402380108425433

Norton, P. (2013). Parliament in British politics. Palgrave Macmillan. https://doi.org/10.1007/978-1-137-32095-7

Palmer, M. (2015). The European Parliament: What It Is· What It Does· How It Works. Elsevier.

Remington, T. F. (2008). The Russian parliament: Institutional evolution in a transitional regime, 1989-1999. Yale University Press. 
Rogers, R., \& Walters, R. (2015). How parliament works. Routledge.

Tsebelis, G., \& Money, J. (1997). Bicameralism. Cambridge University Press. https://doi.org/10.1017/CBO9780511609350

Ziegenhain, P. (2008). The Indonesian parliament and democratization. Institute of Southeast Asian Studies.

\section{Copyrights}

Copyright for this article is retained by the author(s), with first publication rights granted to the journal.

This is an open-access article distributed under the terms and conditions of the Creative Commons Attribution license (http://creativecommons.org/licenses/by/4.0/). 